\title{
Defective neutrophil chemotaxis and raised serum IgE levels in a child with recurrent bacterial infections and eczema
}

\author{
Influence of levamisole
}

\section{J. DE CREE, L. EMMERY, J. TIMMERMANS, R. EECKELS, W. DE COCK, and H. VERHAEGEN}

From the Clinical Research Unit St. Bartholomeus, Antwerp; Department of Paediatrics, A. Dumont Hospital, Genk; and Department of Paediatrics, University of Louvain, Belgium

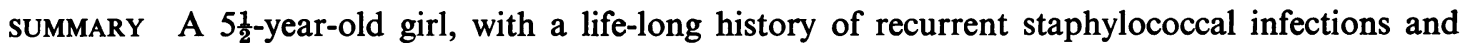
eczematous dermatitis had a defect in polymorphonuclear leucocyte chemotaxis and phagocytosis in autologous serum, a high serum IgE level, and a disturbed $\mathrm{T}$ cell function. Levamisole improved all the immunological abnormalities and there was a dramatic clinical improvement. Discontinuation of therapy with levamisole resulted in gradual deterioration.

We report a child with eczema, recurrent superficial and deep bacterial infections, and raised IgE levels, a syndrome which has already been described (Clark et al., 1973; Hill and Quie, 1974; Hill et al., 1974; Van Scoy et al., 1975). Treatment with levamisole (Symoens and Rosenthal, 1977) led to clinical and immunological improvement.

\section{Case report}

A girl, now $7 \frac{1}{2}$ years old, was born after a normal pregnancy and delivery. Soon after birth she started to suffer continually from severe bronchial, antral and middle ear infections, and eczematous dermatitis. Cultures from sputum, ear secretions, and skin lesions invariably showed the presence of Staphylococcus aureus. At the age of 2 she developed bronchopneumonia, resulting in a lung abscess. Regression was obtained after 2 months of antibiotic therapy, but a residual pneumatocoele required surgical intervention. At the age of 4 she was again hospitalised for right pyopneumothorax. Cultures of pleural effusion yielded Staph. aureus and chest $x$-ray showed multiple radiolucencies. Again the symptoms improved with prolonged antibiotic therapy.

In the same year surgical intervention was needed for a cutaneous block of the antrum. At the age of 5 she was admitted to the University Hospital St

Received 10 June 1977.
Raphaël in Louvain. Humoral and cellular immunity tests at that time gave normal values for the immunoglobulins IgA, IgG, and IgM, complement components $\mathrm{C} 3$ and $\mathrm{C4}$, the epinephrine- and typhoidstimulation test, the phytohaemaglutinin (PHA) lymphoblast transformation test, polymorphonuclear leucocyte (PMN) random migration test, nitrobluetetrazolium test, and the myeloperoxidase test. The abnormalities found were peripheral and bone marrow eosinophilia, high serum IgE levels, and a subnormal lymphoblast response to candidin. At the age of $5 \frac{1}{2}$ she was referred to the Clinical Research Unit St Bartholomeus, Antwerp, for evaluation of humoral and cellular immunity, where levamisole therapy was started and the effects of treatment were followed.

\section{Material and methods}

Chemotaxis assay. $1 \mathrm{ml}$ of a $6 \%$ dextran solution was added to $10 \mathrm{ml}$ heparinised blood and allowed to sediment for about 1 hour. The leucocyte-rich plasma was removed and the leucocyte pellet was washed twice in Hanks's balanced salt solution (HBSS). Cell concentration was adjusted to $1 \times 10^{6}$ $\mathrm{PMN} / \mathrm{ml}$ HBSS. The cells were introduced into the upper compartment of a boyden chamber (Neuro Probe, Bethesda, Maryland) separated by a $5 \mu \mathrm{m}$ millipore filter (Millipore Corp., Brussels) from the chemotactic substances in the lower compartment. After incubation at $37^{\circ} \mathrm{C}$ for 3 hours in humidified 
air, the filters were stained by the haematoxylin method. The PMNs which migrated to the lower surface of the filter were counted in 10 random high power fields (hpf). The chemotactic activity was expressed as the average number of $\mathrm{PMN} / \mathrm{hpf}$ of triplicate determinations. Chemotactic factors were prepared by incubating normal pooled sera with $100 \mu \mathrm{g} / \mathrm{ml}$ lipopolysaccharide (LPS, E. coli 026: B6, Difco Laboratories, Detroit, Michigan) at $37^{\circ} \mathrm{C}$ for 30 minutes. LPS activated sera were heat-inactivated, stored at $-35^{\circ} \mathrm{C}$, and diluted 4 times in HBSS before use.

Phagocytosis. In vitro phagocytosis of Candida albicans by $\mathrm{PMN}$ in autologous and $\mathrm{AB}$ serum was assessed as previously described (Verhaegen $e t$ al., 1976a).

E-rosette test. The E-rosette formation of Tlymphocytes was determined as previously described (Verhaegen et al., 1977).

Lymphoblast transformation test. A mini-culture technique developed by Eysvoogel et al. (1971) was followed. Mitogens were PHA (PHA-M, Difco Laboratories, Detroit) and candidin (Hollister-Stier, Atlanta, Georgia). Results were expressed as the relative mitotic index (RMI), being the ratio between the MI of the patient and the MI of a normal subject.

Delayed hypersensitivity skin tests. Delayed hypersensitivity skin tests were done by intradermal injection of $0.1 \mathrm{ml}$ of antigen into the patient's volar forearm. Results were scored as $\mathrm{mm}$ of erythema and induration present at 48 hours. Antigens were $C$. albicans extract, $1: 100,1: 1000$, and 1:10000 dilutions (Hollister-Stier, Atlanta, Georgia), 5 U PPD (Statens Seruminstitut, Copenhagen, Denmark), and mumps (Eli Lilly, Indianapolis). The DNCB skin test was done by applying a $2 \mathrm{mg}$ sensitising dose followed 2 weeks later with a $100 \gamma, 50 \gamma$, and $25 \gamma$ challenge.

Complement factors and immunoglobulins. The serum haemolytic complement activity (CH50) was determined by a modified method of Mayer (1961), and the serum complement components $\mathrm{C} 3, \mathrm{C} 4$, and $\mathrm{Clq}$ and immunoglobulins IgG, IgM, and IgA by the radial immunodiffusion technique of Mancini et al. (1965) as previously described (Verhaegen et al., 1976b). IgE concentrations were measured by a radioimmunoabsorbent technique using a Phadebas IgE test kit. Normal values ranged between 28 and $700 \mathrm{IU} / \mathrm{ml}$.

\section{Results}

Clinical data. After one month of levamisole treatment, $2.5 \mathrm{mg} / \mathrm{kg}$ daily for 3 consecutive days each week, the patient was hospitalised for staphylococcal pneumonia which progressed to multiple lung abscesses despite antibiotic therapy. 3 months later the clinical picture remained the same. The treatment schedule was then changed to $2.5 \mathrm{mg} / \mathrm{kg}$ levamisole every other day, but the antibiotic therapy remained unchanged. 2 weeks later a dramatic relief of symptoms occurred and the patient was discharged within one month.

From that time until the discontinuation of levamisole, 14 months later, she needed only one course of oral antibiotics during a 10-day period because of bronchopneumonia, which subsided without complications. Otitis never recurred and the superinfection of the skin lesions improved, though a residual eczema persisted.

After discontinuation of levamisole treatment the girl remained in good health for 3 months, thereafter eczema became worse and was complicated with superficial infections. She developed ophthalmitis which was controlled by antibiotics, and after 5 months had to be hospitalised again for bronchopneumonia complicated with pneumatocoele. Levamisole therapy was restarted together with antibiotics and the symptoms subsided after 2 weeks of treatment.

Immunological data. The patient was not receiving antibiotics or suffering from manifest infections when tested. Immunological data before, during, and after discontinuation of levamisole treatment are shown in Tables 1 and 2 and the Fig. Abnormal immunological functions were negative delayed hypersensitivity reactions to mumps and DNCB challenges, high serum IgE, depressed lymphoblast transformation to candidin, low E-rosette forming cells, depressed PMN chemotaxis, and deficient phagocytosis in autologous serum. This serumdependent impairment of phagocytosis could be confirmed by adding the patient's serum to PMNs of healthy subjects (Fig.).

During levamisole therapy the immunological functions returned to normal or improved (Fig.). After 5 months of no levamisole treatment, the IgE levels, PMN chemotaxis, and PMN phagocytosis in autologous serum reached pretreatment values.

\section{Discussion}

Various clinical variants of our patient's disorder have been described (Buckley et al., 1972; Clark et al., 1973; Hill and Quie, 1974; Van Scoy et al., 1975) but 
Table 1 Delayed hypersensitivity skin reactions of the patient to different antigens before and during levamisole therapy

\begin{tabular}{|c|c|c|c|c|c|c|c|c|c|c|c|c|c|}
\hline & \multirow{2}{*}{\multicolumn{2}{|c|}{$P P D(5 U) *$}} & \multirow{2}{*}{\multicolumn{2}{|c|}{ Mumps* }} & \multicolumn{6}{|c|}{ Candida* } & \multicolumn{3}{|c|}{$D N C B \dagger$} \\
\hline & & & & & \multicolumn{2}{|c|}{$1 / 100$} & \multicolumn{2}{|c|}{$1 / 1000$} & \multicolumn{2}{|c|}{$1 / 10000$} & \multirow[b]{2}{*}{$100 \gamma$} & \multirow[b]{2}{*}{$50 \gamma$} & \multirow[b]{2}{*}{$25 \gamma$} \\
\hline & $\boldsymbol{E}$ & $I$ & $\boldsymbol{E}$ & $I$ & $E$ & $\boldsymbol{I}$ & $E$ & $I$ & $\boldsymbol{E}$ & $I$ & & & \\
\hline $\begin{array}{l}\text { Pre-values } \\
6 \mathrm{~m} \\
14 \mathrm{~m} \\
17 \mathrm{~m}\end{array}$ & $\begin{array}{l}0 \\
0 \\
0 \\
0\end{array}$ & $\begin{array}{l}0 \\
0 \\
0 \\
0\end{array}$ & $\begin{array}{r}0 \\
22 \\
20 \\
20\end{array}$ & $\begin{array}{r}0 \\
12 \\
12 \\
13\end{array}$ & $\begin{array}{l}20 \\
23 \\
22 \\
23\end{array}$ & $\begin{array}{l}14 \cdot 5 \\
20 \cdot 5 \\
20 \\
21\end{array}$ & $\begin{array}{l}10 \\
10 \\
11 \\
11\end{array}$ & $\begin{array}{l}10 \\
10 \\
10 \cdot 5 \\
10\end{array}$ & $\begin{array}{l}2 \\
2 \\
2 \\
2\end{array}$ & $\begin{array}{l}2 \\
2 \\
2 \\
2\end{array}$ & $\begin{array}{r}0 \\
+ \\
++ \\
++\end{array}$ & $\begin{array}{l}0 \\
0 \\
0 \\
+\end{array}$ & $\begin{array}{l}0 \\
0 \\
0 \\
+\end{array}$ \\
\hline
\end{tabular}

-Diameter in $\mathrm{mm}$. †0 $=$ no reaction; $+=$ erythema; $++=$ induration. $\mathrm{E}=$ erythema; $\mathbf{I}=$ induration.

all have in common severe deep and superficial staphylococcal infections, eczematous dermatitis, high serum IgE, and defective PMN chemotaxis. The patients of Buckley et al. (1972), Clark et al. (1973), and Van Scoy et al. (1975) also suffered from mucocutaneous candidiasis, and represent a mild degree of T cell dysfunction. Apart from the mucocutaneous candidiasis, our patient resembles the patients reported, but she also had a unique serumdependent phagocytosis defect.

Encouraging results of levamisole treatment have been reported in patients with recurrent infection (De Cree et al., 1974; Vanheule et al., 1976; Verhaegen et al., 1976a; Van Eygen et al., 1976), and levamisole improved the clinical symptoms of our patient. Furthermore, levamisole normalised or improved her defective phagocyte and $\mathrm{T}$ cell functions, which confirms the reported effects of levamisole on phagocyte functions (Verhaegen $e t$ al., 1973; Hoebeke and Franchi, 1973; Schmidt and Douglas, 1976; Anderson et al., 1976) and T cell functions (Biniaminov and Ramot, 1975; Hadden et al., 1975; Lieberman and Hsu, 1976; Whitcomb et al., 1976; Verhaegen et al., 1977).

The physiopathological mechanism which underlies the phagocyte and $T$ cell dysfunctions of these rare disease entities and the interaction of levamisole are still in doubt. Hill and Quie (1974) showed that PMN chemotaxis could be inhibited in vitro by histamine, which is known to increase the intracellular concentration of cyclic AMP, suggesting that the IgE-mediated histamine release in their patients could represent an aetiology for the defective chemotaxis (Hill and Quie, 1974). Of further relevance is the fact that substances which increase intracellular cAMP levels depress both phagocytic and $T$ cell functions (Bourne et al., 1974). Levamisole has been reported to interact with the cyclic nucleotide metabolism: the drug decreased cAMP levels and increased cGMP levels in mouse lymphocytes (Hadden et al., 1975), maintained higher cGMP levels in human chemotactic PMN (Anderson et al., 1976), and restored histamine inhibited E-rosette forming cells in patients with allergies (De Cock et al.,

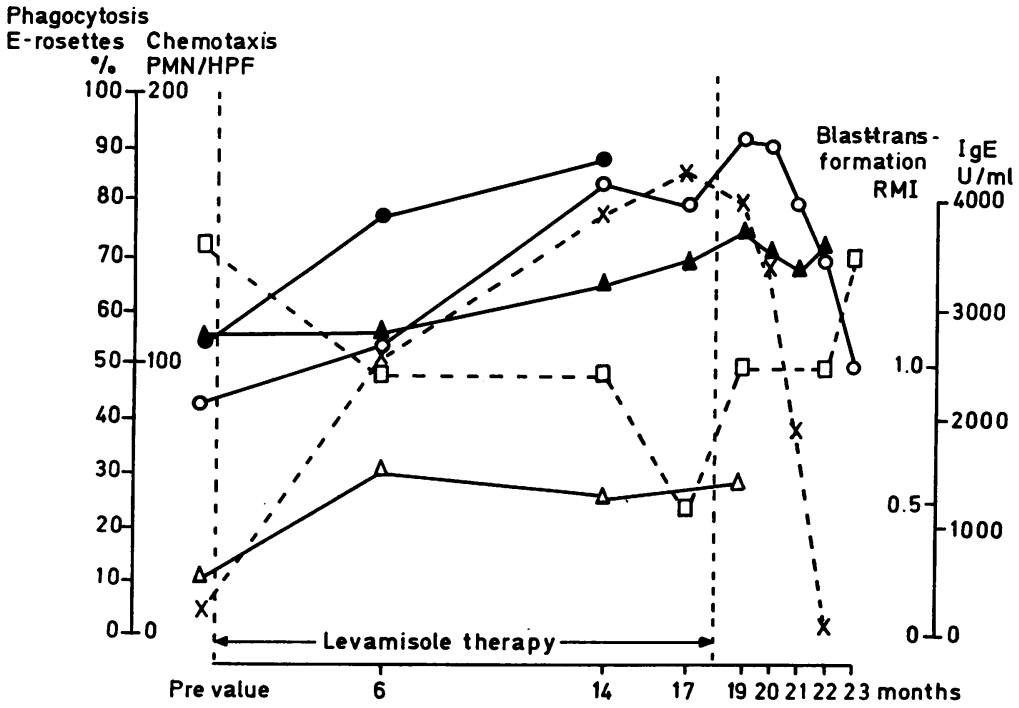

Fig. Effect of levamisole therapy on disturbed immunological functions. $\mathrm{O}=$ phagocytosis of the patient's PMN in autologous serum; $=$ phagocytosis of normal PMN in the patient's serum; $x=P M N$ chemotaxis; $\Delta=$ lymphoblast transformation with candida; $\Delta=$ E-rosettes; $\square=$ serum IgE. 
1977). This may suggest that the phagocyte and $T$ cell dysfunctions of this disease entity may be due to a pathological number of receptors for histamine or substances which increase intracellular cAMP on phagocytes and $T$ cells. The beneficial effects of levamisole on the clinical symptoms and the abnormal immunological functions in our patient fit this hypothesis.

The differences in symptomatology between our patient and those of Hill and Quie (1974), Buckley et al. (1972), Clark et al. (1973), and Van Scoy et al. (1975) may be due to a different distribution of these receptors for histamine or similar substances on $T$ cells and phagocytes. The number of receptors on phagocytes is probably the same but those on T cells may differ. All patients have high serum IgE, suggesting that suppressor $\mathrm{T}$ cells for IgE-production are involved (Okumura and Tada, 1971; Tada et al., 1971). In our case and those of Hill and Quie (1974) some other $\mathrm{T}$ cells may be involved but in the patients of Buckley et al. (1972), Clark et al. (1973), and Van Scoy et al. (1975) T cells were probably greatly involved, accounting for the mucocutaneous candidiasis.

We are indebted to Dr M Peetermans from the Red Cross Blood Transfusion Service in Antwerp for assessing the lymphoblast transformation tests; to G. Bijnens, V. Roels, L. Van der Veken, and $O$. Vogels for technical assistance; to F. Verbruggen for co-ordination; and to $\mathrm{H}$. Vanhove for reviewing the manuscript.

\section{References}

Anderson, R., Glover, A. M., Koornhof, H. J., and Rabson, A. R. (1976). In-vitro stimulation of neutrophil motility by levamisole: maintenance of cGMP levels in chemotactically stimulated levamisole-treated neutrophils. Journal of Immunology, 117, 428-432.

Biniaminov, M., and Ramot, B. (1975). In-vitro restoration by levamisole of thymus-derived lymphocyte function in Hodgkin's disease. Lancet, 1, 464.

Bourne, H. R., Lichtenstein, L. M., Melmon, K. L., Henney, C. S., Weinstein, Y., and Shearer, G. M. (1974). Modulation of inflammation and immunity by cyclic AMP. Science, 184, 19-28.

Buckley, R. H., Wray, B. B., and Belmaker, E. Z. (1972). Extreme hyperimmunoglobulinemia $\mathbf{E}$ and undue susceptibility to infection. Pediatrics, 49, 59-70.

Clark, R. A., Root, R. K., Kimball, H. R., and Kirkpatrick, C. M. (1973). Defective neutrophil chemotaxis and cellular immunity in a child with recurrent infections. Annals of Internal Medicine, 78, 515-519.

De Cock, W., De Cree, J., and Verhaegen, H. (1977). Restoration by levamisole of histamine inhibited $\mathrm{E}$ rosette formation of T-lymphocytes of patients with allergies. International Archives of Allergy and Applied Immunology, 54, 176-182.

De Cree, J., Verhaegen, H., De Cock, W., Vanheule, R., Brugmans, J., and Schuermans, V. (1974). Impaired neutrophil phagocytosis. Lancet, 2, 294-295.
Eysvoogel, V. P., Du Bois, M. J., and Schellekens, P. T. (1971). Mini-culture technique for lymphocytes. Cours International de Transplantation, Lyons, 1971, p. 364. Ed. by J. P. Revillard. SIMEP éditions, Villeurbanne.

Hadden, J. W., Coffey, R. G., Hadden, E. M., LopezCorrales, E., and Sunshine, G. H. (1975). Effects of levamisole and imidazole on lymphocyte proliferation and cyclic nucleotide levels. Cellular Immunology, 20, 98-103.

Hill, H. R., and Quie, P. G. (1974). Raised serum-IgE levels and defective neutrophil chemotaxis in three children with eczema and recurrent bacterial infections. Lancet, 1, 183-187.

Hill, H. R., Quie, P. G., Pabst, M. F., Ochs, H. O., Clark, R. A., Klebanoff, S. J., and Wedgwood, R. J. (1974). Defect in neutrophil granulocyte chemotaxis in Job's syndrome of recurrent 'cold' staphylococcal abscesses. Lancet, 2, 617-619.

Hoebeke, J., and Franchi, G. (1973). Influence of tetramisole and its optical isomers on the mononuclear phagocytic system. Effect on carbon clearance in mice. Journal of the Reticuloendothelial Society, 14, 317-323.

Lieberman, R., and Hsu, M. (1976). Levamisole-mediated restoration of cellular immunity in peripheral blood lymphocytes of patients with immunodeficiency diseases. Clinical Immunology and Immunopathology, 5, 142-146.

Mancini, G., Carbonara, A. O., and Heremans, J. F. (1965). Immunochemical quantitation of antigens by single radial immunodiffusion. Immunochemistry, 2, 235-254.

Mayer, M. M. (1961). Complement and complement fraction. Experimental Immunochemistry, p. 133. Ed. by E. A. Kabat and M. M. Mayer. Thomas, Springfield, tllinois.

Okumura, K., and Tada, T. (1971). Regulation of homocytotropic antibody formation in the rat. III. Effect of thymectomy and splenectomy. Journal of Immunology, 106, 1019-1025.

Schmidt, M. E., and Douglas, S. D. (1976). Effects of levamisole on human monocyte function and immunoprotein receptors. Clinical Immunology and Immunopathology, 6, 299-305.

Symoens, J., and Rosenthal, M. (1977). Levamisole in the modulation of the immune response: the current experimental and clinical state. A review. Journal of the Reticuloendothelial Society, 21, 175-221.

Tada, T., Taniguchi, M., and Okumura. K. (1971). Regulation of homocytotropic antibody formation in the rat. $I$. Feed back regulation by passively administered antibody. Journal of Immunology, 106, 1002-1011.

Van Eygen, M., Znamensky, P. Y., Heck, E., and Raymaekers, I. (1976). Levamisole in the prevention of recurrent upper-respiratory tract infections in children. Lancet, 1, 382-385.

Vanheule, R., De Cree, J., Adriaenssens, H., and De Hauwere, R. (1976). Levamisole therapy for cellular immunologic deficiency with high IgE values. Acta Pediatricia Belgica, 29, 41-46.

Van Scoy, R. E., Hill, H. R., Ritts, R. E., Jr., and Quie, P. G. (1975). Familial neutrophil chemotaxis defect, recurrent bacterial infections, mucocutaneous candidiasis, and hyperimmunoglobulinemia E. Annals of Internal Medicine, 82, 766-771.

Verhaegen, H., De Cree, J., De Cock, W., and Verbruggen, F. (1973). Levamisole and the immune response. New England Journal of Medicine, 289, 1148.

Verhaegen, H., De Cock, W., and De Cree, J. (1976a). Invitro phagocytosis of Candida albicans by peripheral polymorphonuclear neutrophils of patients with recurrent infections: case reports of serum-dependent abnormalities. Biomedicine, 24, 164-170. 
Verhaegen, H., De Cock, W., De Cree, J., and Verbruggen, F. (1976b). Increase of serum complement levels in cancer patients with progressing tumors. Cancer, 38, 1608-1613.

Verhaegen, H., De Cree, J., De Cock, W., and Verbruggen, F. (1977). Restoration by levamisole of low E-rosette forming cells in patients suffering from various diseases. Journal of Clinical and Experimental Immunology, 27, 313-318.
Whitcomb, M. E., Merluzzi, V. J., and Cooperband, S. R. (1976). The effect of levamisole on human lymphocyte mediator production in-vitro. Cellular Immunology, 21, 272-277.

Correspondence to Dr J. De Cree, Clinical Research Unit St Bartholomeus, B-2060 Merksem, Antwerp, Belgium. 